\title{
Article
}

\section{Prescribing opioids in general practice}

Davies, Janice Anne

Available at http://clok.uclan.ac.uk/18937/

Davies, Janice Anne (2017) Prescribing opioids in general practice. Nurse Prescribing, 15 (7). p. 322. ISSN 2052-2924

It is advisable to refer to the publisher's version if you intend to cite from the work.

$10.12968 /$ npre.2017.15.7.322

For more information about UCLan's research in this area go to

http://www.uclan.ac.uk/researchgroups/ and search for <name of research Group>.

For information about Research generally at UCLan please go to http://www.uclan.ac.uk/research/

All outputs in CLoK are protected by Intellectual Property Rights law, including Copyright law. Copyright, IPR and Moral Rights for the works on this site are retained by the individual authors and/or other copyright owners. Terms and conditions for use of this material are defined in the policies page.

\section{CLoK}

Central Lancashire online Knowledge www.clok.uclan.ac.uk

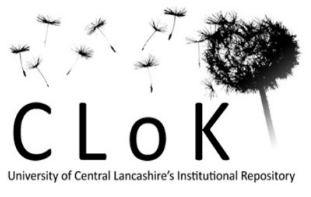


In this scenario you are working as a practice nurse in a large GP practice.

Your local formulary recommends morphine as the first line strong opioid analgesic. Your practice pharmacist has analysed your prescribing data to check whether prescribing is in accordance with the formulary. The analysis reveals that the practice is prescribing a large proportion of nonformulary or second line strong opioids.

In the average UK practice, morphine makes up $30 \%$ of all strong opioids prescribed. In your practice, it makes up just $20 \%$ of all strong opioids prescribed.

Your pharmacist has identified a list of 50 patients on non-formulary or second line strong opioids, all for chronic pain.

\section{Question 1}

How many of these patients would need to be reviewed and the current strong opioid converted to morphine, in order to match the standard of the UK average? 5

Here is a sample of prescriptions from the first five patients on the list:

\begin{tabular}{|l|l|}
\hline A & Oxycodone $80 \mathrm{mg}$ MR tablets, one twice daily morphine $120 \mathrm{mg}$ twice daily \\
\hline B & Oxycodone $120 \mathrm{mg}$ MR tablets, one twice daily morphine $180 \mathrm{mg}$ twice daily \\
\hline C & Fentanyl 25 microgram patch, one every 72 hours morphine $30 \mathrm{mg}$ twice daily \\
\hline D & Fentanyl 100 microgram patch, one every 72 hours morphine $120 \mathrm{mg}$ twice daily \\
\hline e & Oxycodone $40 \mathrm{mg}$ MR tablets, one twice daily morphine $60 \mathrm{mg}$ twice daily \\
\hline
\end{tabular}

\section{Task 1}

Convert each of these regimens to an equivalent twice daily dose of morphine MR. Use this table to help (BNF 72, 2016):

\section{Equivalent doses of opioid analgesics}

This is only an approximate guide (doses may not correspond with those given in clinical practice); patients should be carefully monitored after any change in medication and dose titration may be required

$\begin{array}{lll}\text { Analgesic } & \text { Route } & \text { Dose } \\ \text { Codeine } & \text { PO } & 100 \mathrm{mg} \\ \text { Diamorphine } & \text { IM, IV, SC } & 3 \mathrm{mg} \\ \text { Dihydrocodeine } & \text { PO } & 100 \mathrm{mg} \\ \text { Hydromorphone } & \text { PO } & 2 \mathrm{mg} \\ \text { Morphine } & \text { PO } & 10 \mathrm{mg} \\ \text { Morphine } & \text { IM, IV, SC } & 5 \mathrm{mg} \\ \text { Oxycodone } & \text { PO } & 6.6 \mathrm{mg}\end{array}$


$\mathrm{PO}=$ by mouth; $\mathrm{IM}=$ intramuscular, $\mathrm{IV}=$ intravenous, $\mathrm{SC}=$ subcutaneous

72-hour Fentanyl patches are approximately equivalent to the following 24-hour doses of oral morphine

morphine salt $30 \mathrm{mg}$ daily

morphine salt $60 \mathrm{mg}$ daily

morphine salt $120 \mathrm{mg}$ daily

morphine salt $180 \mathrm{mg}$ daily

morphine salt $240 \mathrm{mg}$ daily

$$
\begin{aligned}
& \equiv \text { fentanyl ' } 12 \text { ' patch } \\
& \equiv \text { fentanyl ' } 25 \text { ' patch } \\
& \equiv \text { fentanyl ' } 50 \text { ' patch } \\
& \equiv \text { fentanyl '75' patch } \\
& \equiv \text { fentanyl ' } 100 \text { ' patch }
\end{aligned}
$$

Based on guidance from the Faculty of Pain, your local policy recommends that patients taking high dose strong opioids (Greater than or equal to $120 \mathrm{mg}$ morphine per day for chronic non-cancer pain) should be reviewed because the risk of harm outweighs the benefits.

\section{Question 2}

How many of the above five patients should be reviewed? 4

\section{Question 3}

What percentage is this? $80 \%$ 